\title{
MISCIGENANDO O CÍRCULO DO PODER: AÇÕES AFIRMATIVAS, DIVERSIDADE RACIAL E SOCIEDADE DEMOCRÁTICA
}

\author{
MISCEGENATING THE CIRCLE OF POWER: AFFIRMATIVE ACTION, RACIAL \\ DIVERSITY, AND DEMOCRATIC SOCIETY
}

\author{
Adilson José Moreira*
}

\begin{abstract}
RESUMO
Este artigo defende a constitucionalidade de cotas raciais em concursos públicos a partir da reconstrução de um argumento comumente utilizado por uma parcela significativa de seus opositores. Muitos deles alegam que ações afirmativas são inerentemente problemáticas por causa da miscigenação do povo brasileiro, um claro empecilho à identificação de seus beneficiários. Segundo esses atores sociais, nosso amalgamento racial e cultural permitiu a construção de uma moralidade pública responsável pela formação de relações harmônicas entre negros e brancos. Embora este trabalho reconheça a relevância do pluralismo racial na formação da identidade nacional brasileira, ele afirma que cotas raciais em concursos públicos são cabíveis porque o grupo que controla quase todas as instituições públicas e privadas brasileiras é racialmente homogêneo. Tal fato é produto de processos sistemáticos de exclusão social que afetam negativamente brasileiros cujos fenótipos denotam origem africana ou ameríndia, a mesma razão pela qual oportunidades profissionais estão concentradas nas mãos dos membros do grupo racial dominante. Com o intuito de contribuir para a transformação dessa situação, este ensaio faz uso do conceito substantivo de diversidade e de certos princípios da Administração Pública para advogar a miscigenação dos círculos do poder por meio de ações afirmativas. Pensamos que isso deve ser visto como um requisito essencial para o avanço da democratização da sociedade brasileira.
\end{abstract}

\section{PALAVRAS-CHAVE}

Ações afirmativas. Miscigenação. Diversidade. Igualdade.

\begin{abstract}
This article defends the constitutionality of racial quotas in selection processes for public employment by reverting the premises of an argument commonly deployed against this policy. Many of its opponents claim that affirmative action is an inherently problematic measure because of the difficulty in identifying its beneficiaries in a racially mixed society such as ours. They also argue that racial and cultural amalgamation allowed the construction of a public morality that favors harmonious race relations among blacks and whites. This paper recognizes the relevance of racial mixing in the formation of the Brazilian national identity, but it supports racially conscious initiatives because those who control the majority of private and public institutions belong to the same racial group. This racial stratification is the product of various processes of social exclusion that affect negatively those of African and Amerindian descent, the same mechanisms that
\end{abstract}

\footnotetext{
* Doutor em Direito pela Universidade de Harvard (2013), Doutor em Direito Constitucional, Mestre em Direito e Bacharel em Direito pela Universidade Federal de Minas Gerais. Professor na Faculdade de Direito da Universidade Presbiteriana Mackenzie (São Paulo, SP, Brasil).E-mail: ajmoreirabh@gmail.com
}

Agradeço os comentários e sugestões de Damião Alves Azevedo, autor cujo excelente trabalho sobre o tema inspirou este artigo [N. do A.]. 
concentrate social opportunities among the members of the dominant racial group. This paper utilizes a substantive notion of diversity and certain principles of public administration in order to advocate racial miscegenation of the circles of power, a necessary step toward the democratization of the Brazilian society.

\section{KEYWORDS}

Affirmative action. Miscegenation. Diversity. Equality.

\section{INTRODUÇÃO}

A adoção de cotas raciais para o acesso a instituições de ensino superior e a cargos públicos tem sido intensamente debatida no nosso País (PENTEADO, 2012; MINHOTO, 2013; MOREIRA, 2013, p. 61-94). Essa discussão demonstra a necessidade de uma reflexão sobre o papel do direito na construção de uma sociedade democrática e racialmente inclusiva no Brasil. De um lado temos uma narrativa desenvolvida por acadêmicos e juristas baseada na ideia de que essa medida representa uma grave ameaça à ordem social porque promove a racialização do povo brasileiro. Parte-se do pressuposto de que existe entre nós uma moralidade pública fundamentada no tratamento igualitário entre grupos raciais; o reconhecimento da multiplicidade das nossas origens possibilita a formação de relações raciais cordiais entre nós. Nossa realidade, afirmam eles, seria muito distinta da história social de outras nações nas quais a discriminação contra negros era sancionada pelo direito (MAGGIE; FRY, 2004; GOSS, 2008). Segundo os defensores dessa perspectiva, programas de ações afirmativas, além de violarem o princípio da igualdade, geram a fragmentação social porque disseminam a percepção de que as pessoas podem ser classificadas segundo critérios raciais. Eles acreditam que a racialização dos indivíduos produz uma série de problemas em uma nação na qual a raça não faz parte do repertório de construção da identidade pessoal. A miscigenação característica da população brasileira estabeleceria referências culturais universais a partir das quais identidades individuais e coletivas são criadas. Isso significaria que o povo brasileiro entende a si mesmo como essencialmente miscigenado; políticas racialistas serviriam apenas para alterar nossa identidade coletiva e nossos padrões de interação social. Os que defendem essa posição acreditam que o sistema jurídico possui um papel bastante específico em uma democracia: ele deve manter os arranjos sociais que representam o consenso cultural sobre os princípios a partir dos quais relações raciais devem ser pautadas (KAUFMANN, 2006; DUARTE, 2007).

Podemos identificar outra formulação do papel do direito no debate sobre políticas públicas que procuram promover a integração de minorias raciais. Ela está centrada na premissa de que a igualdade constitucional tem uma função transformadora, perspectiva que reconhece a relação

Revista da Faculdade de Direito - UFPR, Curitiba, vol. 61, n. 2, maio/ago. 2016, p. 117 - 148 
entre o respeito pelo pluralismo e a defesa da justiça social. Essa visão da igualdade tem como ponto de partida a afirmação de que o sistema jurídico pode ser um mecanismo de emancipação social, entendimento que oferece parâmetros para a justificação de ações afirmativas nas instituições de ensino superior e no serviço público. Os que advogam esses argumentos afirmam que a raça é uma construção social que tem consequências concretas na vida das pessoas: ela legitima diversas formas de exclusão que atuam conjuntamente para promover a estratificação racial, pois serve como parâmetro para a ação arbitrária de agentes públicos e privados ${ }^{1}$. As consequências do racismo presentes nas relações sociais se estendem por várias gerações - são fruto de práticas institucionais que afetam a vida de minorias raciais ao longo do tempo ${ }^{2}$. Argumenta-se que a miscigenação não elimina práticas discriminatórias, nem a concentração do acesso a oportunidades nas mãos daqueles classificados como brancos. Ao contrário dos defensores das teses descritas no parágrafo anterior, os que defendem a constitucionalidade de ações afirmativas sustentam que o racismo não é um problema comportamental decorrente de uma percepção incorreta da realidade, mas um sistema de dominação. Por ser um fator que oprime uma geração após outra, esses autores interpretam o princípio da igualdade dentro de uma linha temporal: ele procura reparar as consequências de processos históricos de exclusão e também pretende estabelecer parâmetros para a construção de uma sociedade igualitária (BARBOSA, 2005; IKAWA, 2006; ROCHA, 1996).

Nossos tribunais afirmaram em diversas decisões que cotas raciais para o ingresso nas instituições de ensino superior são constitucionais, ocasiões nas quais eles formularam argumentos que também legitimam a implementação dessas medidas em concursos públicos. Entretanto, ainda se questiona a compatibilidade dessa última modalidade de ações afirmativas com o mandamento constitucional da igualdade. Algumas decisões judiciais recentes declararam a ilegalidade de políticas afirmativas em concursos públicos porque a elegibilidade para esses certames pressupõe

\footnotetext{
${ }^{1}$ Essa posição tem sido defendida pelos tribunais que reconheceram a constitucionalidade dos programas de ações afirmativas. Ver, por exemplo, BRASIL. Supremo Tribunal Federal. Ação de Descumprimento de Preceito Fundamental $n^{\circ}$ 186. Órgão Julgador: Tribunal Pleno. Relator: Ricardo Lewandovsky. 26 abr. 2012 (afirmando que a raça deve ser compreendida a partir das consequências concretas da mesma na vida das pessoas). BRASIL. Tribunal de Justiça do Rio de Janeiro. Ação Cível $N^{o}$ 2005.001.27.062. Órgão Julgador: $11^{a}$ Câmara Cível. Relator: Cláudio de Mello Tavares. 2005 (classificando a raça como um mecanismo legítimo para a implementação de políticas distributivas porque ela é utilizada para manter minorias raciais em desvantagem material). BRASIL. Tribunal de Justiça do Rio Grande do Sul. Ação Cível $N^{\circ}$ 70013034152. Órgão Julgador: 3a Câmara Cível. Relator: Paulo de Tarso Vieira Sanseverino. 25 maio 2006 (argumentando que o princípio da isonomia deve ser analisado em sua perspectiva material, pois a aplicação pura e simples da igualdade formal permitiria a perpetuação de heranças discriminatórias históricas, que vêm desde a abolição da escravatura).

${ }^{2}$ A compreensão da dimensão temporal da discriminação racial teve um papel importante na argumentação do Supremo Tribunal Federal na decisão que reconheceu a constitucionalidade dos programas de ações afirmativas. O relator reconheceu que as desigualdades entre negros e brancos se reproduzem ao longo do tempo, o que mantém esse grupo em uma situação de permanente desvantagem social. BRASIL. Supremo Tribunal Federal. op. cit. Órgão Julgador: Tribunal Pleno. Relator: Ricardo Lewandovsky. 26 abril 2012, p. 53-65.
} 
que todos os candidatos possuem a mesma formação acadêmica; quaisquer iniciativas de caráter reparatório devem ser feitas no acesso a oportunidades educacionais e não no processo de seleção de candidatos para o funcionalismo ${ }^{3}$. Essa posição fornece argumentos para o questionamento da constitucionalidade e também para a mobilização política contra a legislação que estabelece cotas para negros em concursos públicos nas instituições federais, o que muitos interpretam como um passo decisivo no processo de integração de minorias raciais no mercado de trabalho ${ }^{4}$.

Este artigo desenvolve um dos argumentos presentes na decisão do Supremo Tribunal Federal que reconheceu a constitucionalidade de medidas de inclusão racial: a construção de uma sociedade igualitária requer a adoção de iniciativas que garantam a representação adequada de diferentes grupos raciais nas diversas instituições públicas. Defenderemos essa posição a partir do conceito de diversidade, uma diretriz de natureza jurídica e política que teve origem na jurisprudência norte-americana sobre ações afirmativas. A ideia de que instituições públicas e privadas devem espelhar o pluralismo que existe no corpo social pode ser vista como uma de suas premissas principais; esse preceito afirma então a importância da participação dos diferentes grupos nos processos decisórios, fator legitimador das práticas democráticas. Seguindo esse pressuposto, afirmamos que a adoção de cotas raciais em concursos públicos contribui de forma significativa para a formação de uma Administração Pública democrática, um dos propósitos centrais do atual Estado constitucional.

Embora defenda cotas raciais nos concursos públicos, este artigo não pretende descartar a representação do Brasil como uma nação miscigenada, ideia que muitos acreditam ser mera manipulação ideológica. No lugar de uma visão que articula a noção de igualdade formal e homogeneidade racial para atacar ações afirmativas, adotamos o conceito substantivo de diversidade para a defesa da miscigenação dos círculos do poder. O povo brasileiro pode ser miscigenado, mas o grupo social que controla praticamente todas as nossas instituições públicas e privadas é racialmente homogêneo, uma realidade incompatível com uma sociedade genuinamente democrática. Assim, o conceito de miscigenação não descreve uma realidade histórica e social, mas

\footnotetext{
${ }^{3}$ Ver, por exemplo, BRASIL. Tribunal do Trabalho da $13^{\text {a }}$ Região. Oitava Vara do Trabalho. Processo $n^{\circ} 0131622-$ 23.2015.5.13.0025. Juiz Substituto: Adriano Mesquita Dantas. 18 jan. 2016 (afirmando que cotas em concursos públicos violam o princípio da razoabilidade e da proporcionalidade, além de tocar em pontos não tratados pela ADPF 186). Alguns tribunais estaduais expressaram opiniões semelhantes em decisões anteriores à aprovação de legislação federal que previu cotas raciais no serviço público. Ver, por exemplo, BRASIL. Tribunal de Justiça de Minas Gerais. Mandado de Segurança $n^{\circ}$ 1.0079.05.183566-2/001. Relator: Albergaria Costa, 9 nov. 2006 (alegando que ações afirmativas violam o princípio da igualdade, mandamento constitucional que exige o tratamento igualitário entre todos perante a lei). BRASIL. Tribunal de Justiça do Espírito Santo. Agravo de Instrumento $n^{\circ} 047089000146$. Órgão Julgador: Quarta Câmara Cível. Relator: Carlos Roberto Mignone. 17 fev. 2009 (Argumentando que todos os candidatos a concurso público para procurador municipal estão na mesma condição, o que mostra a desnecessidade de ações afirmativas em concursos públicos).

${ }^{4}$ BRASIL. Lei $n^{\circ}$ 12.990, de 9 de junho de 2014.
} 
um objetivo a ser buscado para a promoção da justiça social. Cotas para homens e mulheres de ascendência africana e ameríndia não apenas garantem o acesso desses indivíduos a milhares de postos de trabalho, mas também permitem que as decisões da Administração Pública possam ser tomadas a partir da perspectiva de todos os que serão afetados por elas, uma condição para a sua democratização. Sustentaremos o argumento de que essas iniciativas são compatíveis com os princípios da moralidade pública, da supremacia do interesse público e da eficiência administrativa. Portanto, ações afirmativas encontram fundamento não apenas nos ideais da igualdade material e justiça social, mas também nos parâmetros que regulam a atuação da Administração Pública.

Em resumo, este artigo procura demonstrar a validade de uma tese apresentada na decisão do Supremo Tribunal Federal que reconheceu a constitucionalidade dos programas de ações afirmativas para minorias raciais: a de que o princípio da diversidade apresenta parâmetros importantes para a construção de uma sociedade racialmente integrada porque permite a realização de propósitos centrais da nossa ordem jurídica ${ }^{5}$. Acreditamos que o argumento utilizado pelo ministro Ricardo Lewandowski é muito persuasivo porque afirma desenvolvimentos teóricos recentes no campo do direito, mas também pensamos que ele precisa ser mais bem delineado e fundamentado. Com esse intuito em vista, demonstraremos ao longo deste texto a plena consonância entre a noção de diversidade e certos preceitos centrais da nossa ordem constitucional, notoriamente com o interesse na construção de uma democracia material e pluralista no Brasil ${ }^{6}$. A demonstração da validade do argumento defendido pelo acórdão acima referido será desenvolvida em três partes. A primeira examina os seguintes pontos: os motivos que levaram instituições públicas e privadas a adotar ações afirmativas nos Estados Unidos, o nascimento do conceito de diversidade dentro da jurisprudência norte-americana e as críticas feitas por progressistas e conservadores a esse preceito. A segunda analisa os argumentos utilizados por certos autores para justificar a diversidade como um elemento importante para o funcionamento de instituições privadas. Em seguida, exploraremos a convergência entre a dimensão substantiva de diversidade e certos princípios da Administração Pública.

\footnotetext{
${ }^{5}$ BRASIL. Supremo Tribunal Federal. Ação de Descumprimento de Preceito Fundamental $N^{o}$ 186. Órgão Julgador: Tribunal Pleno. Relator: Ricardo Lewandowski. 26 abr. 2012 ("Verifica-se, assim, que a Suprema Corte dos Estados Unidos, ao assegurar certa discricionariedade às universidades no tocante à seleção de seu corpo discente, o fez tendo em conta a necessidade de que a busca da heterogeneidade esteja pautada pela correção de distorções histórico-sociais que atuam como obstáculo à concretização dos valores constitucionais da igualdade substancial.”)

${ }^{6} \mathrm{O}$ artigo $3^{\circ}$ da Constituição Federal diz: "Constituem objetivos fundamentais da República Federativa do Brasil: Iconstruir uma sociedade livre, justa e solidária; II- garantir o desenvolvimento nacional; III- erradicar a pobreza e a marginalização e reduzir as desigualdades sociais e regionais; IV- promover o bem de todos, sem preconceitos de origem, raça, sexo, cor, idade e quaisquer outras formas de discriminação.”
} 


\section{EMERGÊNCIA E EVOLUÇÃO DO CONCEITO DE DIVERSIDADE}

\subsection{RETÓRICA RACIAL E AÇÕES AFIRMATIVAS NOS ESTADOS UNIDOS}

Inúmeras instituições públicas e privadas norte-americanas adotaram programas de ações afirmativas nos últimos quarenta anos, providência empregada para que minorias raciais pudessem ter acesso a oportunidades profissionais e acadêmicas, posições até então monopolizadas por pessoas brancas. Isso se tornou necessário em função da política oficial de segregação racial presente no país, regime que começou a ser gradualmente eliminado a partir da segunda metade do século passado, embora ainda exista como uma prática social informal (MASSEY; DANTON, 1998). Esse conjunto de procedimentos discriminatórios permitia a exclusão sistemática de minorias raciais, o que era justificado pela compreensão de que o princípio da igualdade não impunha a necessidade de convivência entre negros e brancos. Segundo o entendimento firmado pela Suprema Corte, aquele mandamento constitucional garantia a igualdade de direitos civis, mas não implicava a igualdade social dos negros, o que era entendido como a possibilidade de circular nos mesmos ambientes frequentados por pessoas brancas. Essa interpretação do princípio da isonomia serviu para justificar a separação espacial e a completa marginalização de afrodescendentes naquela nação; a sociedade norte-americana instituiu um dos mais brutais sistemas de segregação racial da história da humanidade (BLACKMON, 2009).

Essa situação começou a mudar em função de uma série de conjunturas sociais e históricas. Vários cidadãos comuns passaram a questionar a legitimidade da segregação nos tribunais, instituições que reconheceram gradualmente a validade dessas demandas. O movimento dos direitos civis possibilitou o desmantelamento das bases jurídicas do sistema de discriminação racial, o que foi alcançado por meio de uma advocacia estratégica (ARTHUR, 2007, p. 89-157; BELL, 2008, p. 19-73; MACK, 2014). Como observa Derrick Bell, essa mudança pode ser explicada em função da convergência entre a luta dos negros e os interesses das elites políticas daquele país. Ela pode ser parcialmente atribuída às repercussões negativas do regime de segregação racial no plano internacional em um momento no qual os Estados Unidos procuravam se afirmar na posição de líder das sociedades democráticas (BELL, 1979). A manutenção de uma ditadura racial era um obstáculo ao alcance desse objetivo, principalmente em um momento no qual muitos países africanos estavam engajados na luta pela emancipação política. Tendo em vista esses diferentes fatores, o sistema de apartheid que vigorava naquela nação começou a ser paulatinamente desconstruído. A criação de ações afirmativas em certos setores profissionais foi uma das primeiras estratégias adotadas por instituições públicas para eliminar as consequências da estratificação racial

Revista da Faculdade de Direito - UFPR, Curitiba, vol. 61, n. 2, maio/ago. 2016, p. 117 - 148 
(ANDERSON, 2005). Essas medidas foram expandidas após o fim do sistema de segregação racial legalmente sancionado que ali vigorava; havia um consenso de que elas eram necessárias para combater tanto as consequências de séculos de exclusão como também as diferentes formas de racismo institucional ainda presentes. Mas esses programas também começaram a ser adotados voluntariamente, ações que objetivavam aumentar o número de minorias em certos quadros profissionais, medida decorrente da consciência da responsabilidade social das instituições na luta contra a opressão racial (ROOSEVELT JR, 2006, p. 47-116).

Mas o consenso político sobre a necessidade dessas medidas políticas começou a se esvaziar quando certos setores conservadores formularam uma nova ideologia racial em reação às vitórias do movimento pelos direitos civis dos negros norte-americanos. Alguns acadêmicos elaboraram uma leitura diferente das relações raciais naquela sociedade, o que fundamentaria a formulação de uma versão conservadora do ideal de neutralidade racial. Esses autores propuseram uma interpretação da sociedade norte-americana baseada na sua representação como uma nação formada por uma série de grupos étnicos que possuem uma história bastante semelhante. Eles foram discriminados em um primeiro momento, mas começaram a ser assimilados na medida em que internalizaram os valores que estruturam a moralidade pública daquele país (STEINBERG, 1989). Esse modelo de compreensão das relações raciais substituiu o conceito de raça pela noção de etnia, um desenvolvimento teórico que permitiu a desconstrução da existência da representação da população branca como um grupo racial majoritário e detentor de benefícios sociais fechados a minorias. A história norte-americana deixa então de ser pensada como um processo incessante de oposição entre negros e brancos. O que observamos é a presença de conflitos entre grupos étnicos em certos momentos históricos, conflitos que são superados em função da força do caráter assimilacionista daquela sociedade. Esse retrato dos Estados Unidos começou a ser constantemente utilizado por atores sociais contrários a políticas racialmente conscientes. Muitos deles passaram a rejeitar a caracterização da história dos negros como algo significativamente diferente da experiência de grupos étnicos europeus porque todos eles supostamente enfrentaram uma história de exclusão. Dentro dessa lógica, não se pode falar de uma maioria branca que controla quase todas as instituições de poder; os negros também não são um grupo com uma história distinta de todas as etnias existentes naquele país (LOPEZ, 2006, p. 1.001-1.028).

De forma semelhante ao discurso brasileiro da democracia racial, essa narrativa forneceu o substrato ideológico necessário para a mobilização contra ações afirmativas nos Estados Unidos. Essas iniciativas passaram a ser caracterizadas como uma forma de discriminação reversa porque davam tratamento preferencial a negros, o que seria, segundo seus opositores, uma violação do 
princípio da igualdade. O ideal de neutralidade racial defendido durante a luta pelos direitos civis tornou-se um meio de condenação de todas as formas de classificação racial, inclusive aquelas que beneficiam negros (BROWN et al., 2005; CHO, 2009; POWELL, 1997). Segundo os defensores dessa posição, a eliminação das leis discriminatórias criou uma realidade social na qual as pessoas de diferentes grupos raciais têm as mesmas oportunidades. O reconhecimento da necessidade de tratamento igualitário entre negros e brancos teria causado uma mudança considerável nas atitudes individuais na esfera pública e na esfera privada. Para esses acadêmicos e políticos, a conjunção desses fatores possibilitou a superação da consciência de identidade racial; isso significa que a discriminação acontecida no passado não afeta mais as oportunidades de minorias no momento presente. Seguindo o mesmo tipo de raciocínio de acadêmicos e políticos brasileiros, eles sistematicamente negam quaisquer correlações entre status racial e desvantagem material (KAUFMANN, 2005; POWELL, 2009).

Essa narrativa racial forneceu as bases para uma campanha de contestação da necessidade de ações afirmativas nos tribunais. Sendo instituições compostas por agentes que reproduzem discursos dominantes no meio cultural, eles também incorporaram o discurso da neutralidade racial que, além de ser defendido como princípio de política pública, também adquiriu o status de parâmetro de interpretação da igualdade. Geralmente chamada de colorblindness, essa narrativa propõe que a justiça racial demanda o tratamento simétrico entre negros e brancos em todas as situações. Ao rejeitar decisões anteriores que entendiam a igualdade a partir de um ponto de vista emancipatório, muitos tribunais norte-americanos passaram a argumentar que todas as formas de classificações raciais são potencialmente perigosas, inclusive aquelas que beneficiam minorias raciais. Para os que defendem essa perspectiva, a igualdade tem um caráter fundamentalmente procedimental; ela é um princípio que analisa a racionalidade das distinções entre indivíduos. Baseados nesse raciocínio, certos juristas influentes equipararam programas de ações afirmativas a políticas racialmente discriminatórias, o mesmo argumento utilizado por muitos críticos dessas iniciativas governamentais no Brasil (SCALIA, 1979; ABRAHAM, 1985; DUARTE, 2005; AZEVEDO, 2004).

\subsection{O CONCEITO DE DIVERSIDADE NA JURISPRUDÊNCIA NORTE-AMERICANA}

A discussão sobre a constitucionalidade dos programas de ações afirmativas nos Estados Unidos sempre esteve centrada na questão da correlação entre o uso de classificações raciais e o alcance de algum interesse estatal legítimo. Aqueles que defendem essas políticas públicas 
apresentam uma série de argumentos para justificá-las, tais como a contribuição dessas medidas ao combate à discriminação racial, a defesa de um ideal de justiça identificado com a noção de igualdade de resultados, a formação de profissionais motivados a atender grupos minoritários e a criação de modelos que possam inspirar positivamente membros de minorias raciais (DWORKIN, 1976, p. 223-230). Essas teses foram rejeitadas pelos tribunais na medida em que a opinião pública abraçou o ideal de colorblindness formulado no meio acadêmico e político. Essa doutrina alcançou status constitucional em uma decisão que considerou a constitucionalidade de cotas raciais em uma instituição de ensino superior. A Faculdade de Medicina da Universidade da Califórnia decidiu reservar um determinado número de vagas para minorias raciais para tornar seu corpo discente mais diversificado. Um candidato branco questionou a validade desse programa porque ele supostamente teria sido classificado entre as cem vagas disponíveis caso a instituição não tivesse implementado cotas raciais.

Nenhuma das justificativas para a implementação de ações afirmativas acima referidas conseguiu sobreviver ao teste de escrutínio utilizado para a avaliação da constitucionalidade desses programas. O ministro Powell, autor do voto que representou a opinião majoritária, argumentou que todas as classificações raciais, independentemente dos seus objetivos, devem ser submetidas à mais rígida forma de escrutínio judicial. Segundo ele, classificações raciais são sempre perigosas porque desestabilizam a credibilidade das instituições democráticas. Tendo em vista esse raciocínio, ele rejeitou o argumento segundo o qual ações afirmativas seriam legítimas porque procuram remediar as consequências da discriminação racial. Essa tese não teria legitimidade porque não há como estabelecer uma relação direta entre a situação presente dos membros de uma minoria racial e os possíveis eventos históricos que teriam sido responsáveis por ela. O objetivo de remediar a discriminação racial só seria compatível com o texto constitucional quando tanto os agentes estatais responsáveis por um ato dessa natureza quanto suas vítimas pudessem ser identificadas, asseverou Powell. Além disso, afirmou o ministro, essa tese poderia ser utilizada por todos os grupos étnicos presentes na sociedade norte-americana, porque todos eles tiveram a mesma história social. Seguindo uma das premissas da ideologia da colorblindness, Powell afirmou não existir uma oposição histórica entre uma maioria branca e uma minoria negra, mas sim conflitos entre grupos étnicos que lutam pelas mesmas oportunidades sociais ${ }^{7}$.

Esse retrato da sociedade norte-americana como um mosaico de grupos étnicos que têm a mesma história social serviu para justificar uma interpretação procedimental da igualdade. Mais

\footnotetext{
${ }^{7}$ Ver ESTADOS UNIDOS. Suprema Corte dos Estados Unidos. Bakke v. Regents of the University of California, 438 U.S. 265 (1978).
} 
especificamente, ele corroborou um recurso retórico baseado no argumento segundo o qual negros e brancos encontram-se na mesma situação, motivo da exigência de tratamento simétrico entre os membros desses grupos em todas as situações. Seguindo essa direção, Powell rejeitou o argumento segundo o qual ações afirmativas são necessárias para aumentar a representatividade de minorias em certas posições sociais, o que permitiria a criação de role models para minorias. Isso seria ilegal porque parte-se do pressuposto de que as pessoas só se identificam com membros do seu próprio grupo étnico. Ele asseverou que essa tese viola o princípio da igualdade porque classificações raciais não podem ser um fim em si mesmas: estabelecer diferenciações entre indivíduos que estão igualmente situados não é nada mais do que pura discriminação racial, o que contraria os princípios republicanos que sustentam a sociedade norte-americana. Ele alegou também que cotas raciais impedem a competição entre indivíduos que estão em igualdade de condições. Isso não apenas caracteriza uma forma de discriminação contra pessoas brancas, mas também contra negros, porque eles são obrigados a suportar estigmas sociais em nome de todo o grupo racial. Assim, esse argumento legitimou o argumento da inocência branca, tese até hoje utilizada por opositores dessas medidas (HUNT II, 2005; DWORKIN, 1976).

Mas nem todos os argumentos favoráveis à implementação de ações afirmativas foram descartados. Powell proclamou que a criação de um ambiente acadêmico diversificado justifica a utilização de classificações raciais. Ele reconheceu a noção de diversidade como um princípio suficientemente forte para o alcance de um interesse estatal importante. Para ele, o conceito de diversidade tem relevância central para a formação de um ambiente acadêmico capaz de proporcionar o enriquecimento da experiência educacional. Aqueles que estão nessa situação poderão interagir e discutir diversos temas com pessoas que possuem experiências sociais distintas, o que preparará melhor esses futuros profissionais para atuar em uma sociedade pluralista. Isso significa que estudantes serão expostos a perspectivas que muito possivelmente estariam ausentes em uma sala de aula racialmente homogênea. Entretanto, a criação de um corpo discente diversificado não pode ser feita pela utilização de cotas raciais, porque elas violam a igualdade ao impedir que todas as pessoas possam disputar as mesmas vagas. As universidades estão autorizadas a considerar a raça no processo de seleção dos candidatos, mas desde que outros fatores tenham o mesmo peso - perspectiva que gerou grande crítica por parte de acadêmicos (FARELL, 2009; GUINIER, 2000).

A Suprema Corte dos Estados Unidos voltou a caracterizar a diversidade como um interesse estatal que justifica o uso de classificações raciais no julgamento sobre a constitucionalidade de ações afirmativas na Faculdade de Direito da Universidade de Michigan. 
Aquele tribunal novamente reconheceu a relevância da diversidade em uma sociedade composta por uma infinidade de grupos raciais. Mais do que uma prática que procura expor alunos universitários a uma multiplicidade de experiências culturais, essa segunda formulação de diversidade tem um caráter mais substantivo. O voto principal a considerou como um interesse estatal que facilita a democratização do acesso ao poder: ações afirmativas são compatíveis com o princípio da igualdade porque podem contribuir para a efetivação do direito de participação e representação no processo decisório. O conceito de diversidade serve então para garantir um funcionamento mais democrático das instituições sociais, ao permitir que os interesses de diversos grupos que compõem uma nação sejam considerados nos vários processos de deliberação ${ }^{8}$.

De acordo com a decisão judicial sob análise, a diversidade presente no ambiente acadêmico serve como ponto de partida para a existência de instituições mais democráticas. Ela se torna ainda mais legítima quando permite que a composição das instituições públicas e privadas reflita a pluralidade existente na realidade social. Para a ministra que escreveu o voto majoritário, a criação de uma liderança que expressa a diversidade presente na sociedade aumenta a credibilidade dos órgãos públicos e privados, pois afasta a percepção de que o jogo democrático representa apenas os interesses de grupos específicos. Isso significa que as instituições devem procurar selecionar candidatos de diversos estratos sociais, e não apenas aqueles que estão entre os grupos mais economicamente ou socialmente privilegiados ${ }^{9}$. A formulação do conceito de diversidade exposto nessa decisão apresenta parâmetros mais robustos para a defesa de programas de ações afirmativas baseados na raça dos indivíduos. Ao defender a criação de uma liderança representativa, ela reconhece a esfera pública como um campo de luta pela dominação social. Segundo a Suprema Corte dos Estados Unidos, a participação de membros de todos os grupos étnicos e raciais na vida pública deve ser vista como um interesse estatal legítimo. A diversidade expressa então um valor constitucional porque permite a cooperação social entre grupos raciais na criação de uma sociedade atenta às particularidades da experiência desses segmentos. Desse modo, a consideração da raça se justifica não apenas em função da diferença de opiniões, mas principalmente porque pode promover a integração de classes de pessoas que têm sido historicamente excluídas de aspectos essenciais da vida pública (ESTLUND, 2005, p. 15-20).

\footnotetext{
${ }^{8}$ ESTADOS UNIDOS. Suprema Corte dos Estados Unidos. Grutter v. Bollinger, 539 U.S. 306 (2003).

${ }^{9}$ ESTADOS UNIDOS. Suprema Corte dos Estados Unidos. Grutter v. Bollinger, 539 U.S. 306 (2003) ("Torna-se então necessário abrir o caminho para a liderança de indivíduos talentosos e qualificados de todos os grupos raciais e étnicos para que se possa criar um grupo de líderes que tenha legitimidade aos olhos dos cidadãos. Todos os membros de nossa sociedade precisam ter confiança na abertura e na integridade das instituições educacionais que proporcionam treinamento profissional.”)
} 


\subsection{CRÍTICA ACADÊMICA DO CONCEITO DE DIVERSIDADE}

A noção de diversidade tem sido igualmente atacada por detratores e por defensores de ações afirmativas nos Estados Unidos. Conservadores alegam que ela reproduz a noção equivocada de que grupos raciais possuem opiniões diferentes por causa da cor da pele. Segundo eles, essa premissa não apenas reforça concepções essencialistas de identidade racial, mas também contribuem para a formação de estereótipos baseados na percepção de que opiniões de membros de grupos minoritários são sempre racializadas. Além disso, eles classificam ações afirmativas como medidas que fomentam a estigmatização racial por não serem meritocráticas; muitos alegam ainda que o interesse na diversidade serve apenas para mascarar políticas reparatórias. Esses programas seriam discriminatórios contra pessoas brancas, indivíduos que não têm culpa por atos arbitrários cometidos por seus antepassados. Para os críticos de ações afirmativas, o conceito de diversidade não pode ser adequadamente sustentado porque não se compara a outros interesses estatais tidos como suficientemente persuasivos como, por exemplo, a segurança nacional. Muitos não apenas criticam o conceito de diversidade como fundamento de ações afirmativas, mas também condenam quaisquer tipos de tratamento preferencial para negros. Eles defendem o ideal de colorblindness como um preceito central de justiça racial; argumenta-se que a superação da discriminação racial requer a eliminação imediata de toda e qualquer classificação racial, pois elas impedem a construção de um senso de solidariedade (KENNEDY, 2013, p. 147-165).

Progressistas atacam o conceito de diversidade porque não o consideram como uma justificação adequada para ações afirmativas. Segundo o entendimento desses acadêmicos, elas devem ser vistas como iniciativas que procuram atacar o racismo estrutural que existe na sociedade norte-americana. Mais do que isso, eles defendem uma compreensão substantiva de igualdade, princípio que justifica medidas reparatórias e distributivas. Os defensores dessa visão de igualdade acreditam que a diversidade seria apenas um artifício ideológico que ignora contextos sociais e históricos; a sua lógica apenas considera os benefícios futuros que pode causar. Ignora-se assim a necessidade de correção das consequências atuais de práticas discriminatórias ainda presentes na sociedade que precisam ser analisadas de forma ampla (BELL, 2003). Essa visão impede o reconhecimento das várias formas por meio das quais raça e classe colocam minorias em uma situação de desvantagem estrutural, eliminando a necessidade de profundas mudanças no funcionamento das instituições sociais. A diversidade serve então apenas para desvirtuar o sentido substantivo da noção de igualdade, princípio que justifica medidas baseadas na necessidade de correção dos efeitos da estratificação racial (KENNEDY, 2013, p. 94-103). 


\section{DIVERSIDADE COMO PRINCÍPIO DE POLÍTICA PÚBLICA E COMO TÉCNICA GERENCIAL}

Embora seja atacada por diferentes setores, podemos afirmar que a diversidade é hoje uma política institucional amplamente adotada por instituições do setor público e do setor privado nos Estados Unidos. Muitos a concebem como uma forma positiva de integração social de grupos minoritários, segmentos cuja mobilização transformou a vida política daquele país. O conceito de minoria adquiriu relevância sociológica e política em função dos movimentos de libertação ocorridos principalmente a partir da segunda metade do século passado em vários lugares do mundo. Muitos grupos oprimidos começaram a questionar a legitimidade de práticas discriminatórias, início de uma luta contra sistemas de opressão que tinham dimensões jurídicas e políticas. Alguns deles conseguiram alcançar a igualdade formal em relação aos membros dos grupos dominantes, embora mecanismos de exclusão ainda os mantenham em uma condição subalterna. Podemos dizer que a luta pelos direitos civis dos negros norte-americanos é o exemplo paradigmático desse processo que resultaria mais tarde na afirmação da diversidade racial como um valor seguido por diferentes instituições preocupadas com a responsabilidade social (SKRENTNY, 2002).

Essa luta política também trouxe à tona a discussão sobre o pluralismo como um valor social que tem repercussões também no setor privado. O conceito de diversidade tem como base a premissa de que o pluralismo é uma referência relevante para o desenho de políticas institucionais. Traços identitários construídos ou atribuídos a certos segmentos sociais determinam a experiência social de seus membros, sendo que essas características são frequentemente utilizadas para designar o lugar que eles podem ocupar - mecanismo responsável pela reprodução de relações assimétricas de poder. Assim, a noção de diversidade como um valor institucional se refere a coletividades cujos membros possuem uma experiência social específica em função dos processos de estratificação. Ela não pretende sugerir ou afirmar identidades essenciais, mas reconhece que experiências culturais distintas produzem percepções sociais diferentes (BELL, 2007, p.4).

Mais do que uma iniciativa que objetiva remediar práticas discriminatórias, a diversidade também designa uma estratégia que pode trazer ganhos consideráveis para as instituições que a empregam. Essas vantagens estão relacionadas com o aumento da competitividade das empresas no mercado, com a maior qualidade das respostas às demandas feitas a essas instituições e com o dever moral de promoção da inclusão social. Um dos elementos mais importantes para a mudança da lógica das ações afirmativas teve início com a percepção de que a melhoria do desempenho das empresas privadas depende da capacidade dessas organizações em responder demandas decorrentes 
do pluralismo no plano nacional e internacional. Parte-se do pressuposto de que a diversidade pode facilitar a implementação de estratégias e aumentar a lucratividade dos negócios. Isso porque a globalização das economias exige a contratação de pessoas que possam compreender as particularidades culturais e políticas de diferentes nichos de mercados em vários lugares do mundo. Uma força de trabalho racialmente e culturalmente homogênea seria menos capaz de tratar questões que podem surgir das demandas geradas pelo pluralismo cultural. Os diferentes grupos sociais têm interesses e exigências distintos e os que não possuem competência cultural para com eles negociar enfrentam grandes dificuldades. A diversidade adiciona um valor considerável às empresas que a empregam por causa do aumento de sua competitividade no mercado (COX; BLAKE, 1991, p. 45$55)$.

Aqueles autores que escrevem sobre o tema afirmam que a diversidade aumenta a competitividade porque melhora a eficiência gerencial das empresas. Ela representa uma vantagem importante, pois permite que as instituições respondam aos interesses de diversos grupos da forma mais adequada possível. Acredita-se que um corpo de funcionários diversificado melhora o desempenho da instituição ao incrementar a capacidade de análise e solução de problemas. Esses estudos demonstram que as perspectivas trazidas por pessoas de diferentes origens sociais e com experiências diversas fazem com que a capacidade institucional de solução de problemas seja superior à daquelas empresas cujos corpos de funcionários são uniformes. Empresas que criam um corpo de funcionários diversificado criam meios para que a troca de novas ideias aumente, o que é algo particularmente desejável em um mercado no qual grupos minoritários possuem poder de compra cada vez maior (HAWKINGS, 2012, p. 88-90).

Além das vantagens decorrentes da eficiência gerencial dos negócios, a diversidade também tem sido adotada por instituições privadas com base na noção de responsabilidade social. A sua promoção começou com a percepção de que se tratava de um dever moral, principalmente em uma sociedade marcada por um passado de opressão racial. Segundo esse raciocínio, a prática da diversidade cria oportunidades que permitem a contribuição das empresas para a formação de uma sociedade mais justa. Essas empresas devem considerar o impacto de suas atividades no bem-estar da comunidade, e a contribuição que elas podem fazer para a melhoria das condições de vida de grupos minoritários é um excelente indício. A incorporação de membros de vários segmentos sociais possibilita o acesso a oportunidades profissionais, além de fazer com que eles participem da tomada de decisões que têm o potencial de afetar toda a sociedade. A governança corporativa se aproxima da ideia de que as decisões devem ser tomadas por pessoas que representam a variedade de grupos e de interesses que existem na realidade. Portanto, a justificação da prática da diversidade 
não se restringe ao caráter reparatório das ações afirmativas, mas também se justifica pelo seu papel inclusivo (HAWKINGS, 2012, p. 88-90).

\section{AÇÕES AFIRMATIVAS, INCLUSÃO RACIAL E SOCIEDADE DEMOCRÁTICA}

\subsection{DISCRIMINAÇÃO RACIAL E AÇÕES AFIRMATIVAS}

Uma vez analisada a noção de diversidade como um princípio jurídico e como uma política institucional, devemos agora verificar se ela pode ser aplicada à nossa realidade social. A resposta a essa pergunta deve começar com um exame da situação de minorias raciais no nosso País. A população de origem africana e ameríndia sempre esteve submetida a um processo histórico de exclusão sistemática: esses dois grupos sociais passaram por períodos de escravização em diferentes momentos da história, foram impedidos de exercer direitos mesmo após a instauração de uma constituição de caráter liberal, eram classificados como raças inferiores por políticos que queriam criar uma população branca, além de terem sido preteridos em benefício de imigrantes brancos e asiáticos em função de políticas imigratórias. As instituições estatais sempre estiveram diretamente implicadas nesse processo: a raça sempre tem sido um parâmetro de regulação do acesso ao mercado de trabalho durante toda a história do Brasil. A situação atual não é diferente: inúmeros estudos sociológicos e históricos demonstram que afrodescendentes sofrem as consequências de processos discriminatórios que os mantêm em uma situação de perene marginalização.

Negros e negras são vítimas preferenciais da violência policial, permanecem menos tempo na escola, ganham menos da metade do salário de homens brancos, são vítimas constantes de injúria racial, permanecem invisíveis nos meios de comunicação de massa e estão estruturalmente excluídos de cargos de poder nas instituições públicas e nas instituições privadas. Essa realidade decorre em grande parte da permanência de estereótipos culturais que legitimam práticas excludentes em muitas esferas da vida social, processo mascarado pela influência da noção de neutralidade racial no âmbito cultural e político. Mas, nas três últimas décadas, a rearticulação dos movimentos sociais após a restauração da democracia, o afastamento parcial do discurso oficial da democracia racial e a emergência de uma nova cultura constitucional possibilitaram a formulação de uma agenda política voltada para a questão da justiça racial. Várias instituições estatais adotaram programas de ações afirmativas que procuram facilitar o acesso de brasileiros de origem africana e ameríndia às instituições de ensino superior e a cargos públicos (TELLES, 2005; HANCHARD, 1994, p. 31-76; HASENBALG, 2005, p. 252-275). 
A importância do debate sobre ações afirmativas requer uma definição precisa dessa política pública, bem como de seus objetivos e de sua justificação constitucional. Esse termo designa um conjunto de medidas utilizadas por instituições públicas e privadas que visam incrementar o acesso de grupos minoritários a oportunidades acadêmicas e profissionais. Elas pretendem suplantar os problemas gerados pela existência de diferentes formas de discriminação que impedem a inclusão social desses grupos, processos cuja operação nem sempre pode ser eliminada por políticas públicas universais. Na verdade, eles restringem ou impedem o gozo de direitos destinados a todos, o que subverte o ideal democrático segundo o qual todos os indivíduos devem ser tratados com a mesma consideração e respeito. As ações afirmativas são políticas sociais destinadas à criação de uma representação significativa de membros de grupos minoritários nas posições de poder existentes dentro da sociedade. Como uma prática institucional, elas adotam procedimentos que utilizam os mesmos critérios responsáveis pela exclusão social para garantir a inclusão de minorias. Agentes públicos e privados conferem um tratamento preferencial a membros de grupos que estão em uma situação de desvantagem durante um determinado período de tempo.

Em relação aos seus objetivos, as ações afirmativas procuram construir um futuro igualitário, ao concorrer para a realização da justiça social, o que pode acontecer pela garantia da igualdade de resultados. No lugar de uma concepção de igualdade baseada na noção de tratamento simétrico, essas iniciativas incorporam uma noção de igualdade que reconheça a diferença estrutural entre grupos. Os agentes públicos e privados que implementam esses programas não discriminam certos indivíduos para garantir privilégios a outros; eles atuam para que grupos minoritários tenham acesso a oportunidades que geralmente não estão acessíveis a eles. Ao contrário das várias formas de discriminação negativa, as ações afirmativas devem ser classificadas como uma discriminação positiva, pois não há a intenção de subjugar e sim de promover a inclusão. Mais uma vez, ações afirmativas partem então da noção de igualdade de resultados, um princípio que justifica iniciativas que têm por objetivo garantir que membros de diversos grupos tenham o mesmo nível de sucesso social (BOLYAN, 2002, p. 117-123; CROSBY, 1991, p. 13-18).

Como demonstrado anteriormente, essa forma de política pública tem sido justificada de duas formas. Ações afirmativas são defendidas a partir do princípio de justiça corretiva, pois procuram remediar as consequências de injustiças históricas cujas consequências se perpetuam ao longo do tempo. Elas então procuram anular os efeitos atuais dos mecanismos discriminatórios que criaram formas de estratificação racial que ainda repercutem no presente. Ações afirmativas também encontram fundamentação na justiça redistributiva, pois esse preceito procura alocar oportunidades sociais tendo em vista a situação real dos indivíduos no meio social. De certa forma, 
essas duas dimensões da justiça estão relacionadas, porque levam em consideração as diferenças estruturais existentes entre grupos sociais (ROSENFELD, 1985, p. 860-865).

Mas essas medidas de inclusão racial também têm sido caracterizadas como uma política de caráter integracionista. O objetivo de se construir uma sociedade na qual pessoas de diferentes grupos sociais possam estar adequadamente representadas nas posições de poder aparece aqui como um ideal político e moral a ser alcançado. Mais do que reparar os erros do passado histórico, pretende-se criar mecanismos para que as instituições públicas espelhem o pluralismo social, o que contribui para a legitimidade do processo democrático (ESTLUND, 2005, p. 2-40). Entende-se por integração a possibilidade de membros dos diversos segmentos poderem participar de forma equitativa nas principais atividades sociais e políticas. $\mathrm{O}$ alcance desse ideal exige a utilização de medidas racialmente conscientes, para que a realidade multirracial da população possa ser refletida nas diversas instituições que existem em uma dada sociedade. Não se procura apenas garantir uma mera representação, mas sim fazer com que os diferentes grupos possam efetivamente participar do processo decisório, condição para a realização de uma democracia participativa. Assim, os que justificam ações afirmativas a partir dessa perspectiva acreditam que a equidade em uma sociedade multirracial só pode ser alcançada por meio da presença de todos os grupos que formam a sociedade nas diversas organizações públicas e privadas (KENNEDY, 2013, p. 106-108).

\subsection{AÇÕES AFIRMATIVAS E IGUALDADE CONSTITUCIONAL}

Programas de ações afirmativas foram introduzidos no Brasil nos últimos quinze anos; eles procuram facilitar o acesso de minorias raciais a universidades e cargos públicos. Segundo seus defensores, o nosso texto constitucional fornece amplo fundamento para esses programas, pois trata-se de documento que estabelece a erradicação das desigualdades como um objetivo central da nossa ordem constitucional. O sistema jurídico brasileiro consagra dois sentidos do princípio da igualdade: a formal e a material.

O primeiro determina o tratamento igualitário a todos os membros da comunidade política, mandamento que reconhece não apenas o mesmo status jurídico, mas também comanda o igual respeito e consideração a todos. Ele está baseado no universalismo das normas jurídicas, o que afirma a necessidade de que elas sejam dirigidas a todas as pessoas.

O segundo, por outro lado, refere-se à isonomia proporcional, pois devem ser reconhecidas as diferenças estruturais que existem entre os indivíduos, de forma que uma paridade mínima entre eles possa ser alcançada. Em função disso, as instituições estatais devem adotar políticas públicas 
inclusivas, o que deve ser visto como uma obrigação estatal. Dessa forma, o conceito de igualdade material está diretamente relacionado com o propósito de criação de uma democracia substantiva no Brasil, condição para a existência de uma sociedade igualitária. Mais uma vez, não se pode esquecer que o texto constitucional estabelece a erradicação da marginalização como um propósito central da nossa ordem jurídica; isso significa que a eliminação das disparidades sociais é um interesse público primordial. As políticas de ação afirmativa têm um papel importante nesse processo, uma vez que elas garantem acesso a oportunidades acadêmicas e também fomentam a integração social de minorias raciais no mercado de trabalho (SILVA, 2011, p. 211-221).

Essas formulações do princípio da igualdade adquirem maior sentido quando as analisamos sob a luz da filosofia política subjacente à nossa Constituição Federal. Observamos que a construção de uma sociedade igualitária é um dos objetivos centrais da ordem jurídica. Esse compromisso com uma concepção substantiva da cidadania justifica a adoção de políticas públicas que têm a função de alcançar a inclusão social. Esse propósito político e jurídico faz parte do programa constitucional de transformação que requer a articulação entre diferentes categorias de direitos, além da responsabilidade estatal com a promoção da justiça. O caráter emancipatório da igualdade tem a finalidade de eliminar os processos de estratificação decorrentes das correlações entre status cultural e status material. Acredita-se que o caminho para uma sociedade justa requer o combate dos mecanismos culturais que levam à marginalização econômica, pois esses dois elementos reforçam a estratificação social. O caráter transformador do nosso texto constitucional implica uma opção política pela construção de uma sociedade racialmente justa, o que significa um distanciamento de uma compreensão do Estado como um ator politicamente neutro. Consequentemente, as instituições estatais devem sempre procurar integrar grupos sociais, uma exigência do nosso sistema jurídico (KLARE, 1998; BARROSO, 2009, p. 51-91).

Os argumentos expostos acima não são meras figuras de retórica jurídica. Recentemente, os tribunais brasileiros começaram a enfatizar esse caráter transformador da isonomia constitucional. Mais do que fundamentar o tratamento simétrico e também políticas redistributivas, esse mandamento constitucional adquire um novo caráter na nossa jurisprudência. Para que ele possa atuar dessa maneira, as instituições estatais devem tratar a isonomia como um princípio que articula demandas de redistribuição e demandas de reconhecimento da igual dignidade das pessoas.

Partindo da premissa de que existe uma relação direta entre status cultural e desvantagem material, esses tribunais afirmam a necessidade de mudar práticas sociais que reproduzem ao 
mesmo tempo estereótipos negativos e exclusão material. O compromisso constitucional com a justiça social e com o pluralismo justifica iniciativas destinadas a promover a emancipação ${ }^{10}$.

\subsection{DIVERSIDADE RACIAL COMO INSTRUMENTO DE CONSTRUÇÃO DA IGUALDADE}

Como observa Marçal Justen Filho, a atividade da Administração Pública está diretamente relacionada com a realização dos direitos fundamentais, o que acontece quando as instituições estatais asseguram as condições para a realização de necessidades da coletividade. A garantia dos direitos fundamentais depende então das direções que as instituições públicas e privadas seguem na perseguição dos objetivos que estão firmados no texto constitucional, como, por exemplo, o alcance da justiça social.

Os princípios da Administração Pública surgem então como uma série de diretrizes que devem ser obedecidas para a promoção da dignidade humana por meio dos direitos fundamentais (JUSTEN FILHO, 2014, p. 91-94). Essa perspectiva reflete a influência do neoconstitucionalismo na reflexão sobre as funções da Administração Pública. Sendo uma doutrina que atribui ao Estado o papel de agente de transformação social, ela estabelece novas diretrizes para a ação estatal; entre elas está o alcance da justiça social por meio da integração de grupos minoritários, uma vez que a erradicação da marginalização é um objetivo central da nossa ordem jurídica. Nesse sentido, podemos classificar a moralidade como um princípio informador da Administração Pública, preceito que incorpora necessariamente a noção de que a satisfação dos direitos fundamentais constitui uma dimensão objetiva desse conceito. Mais do que um pressuposto de validade dos atos da administração, a moralidade pública está ligada aos preceitos constitucionais que estabelecem os objetivos da nossa ordem jurídica. Ela sofre então a influência da redefinição do Estado como uma instância que deve fomentar a emancipação. A moralidade pública serve como um critério de racionalidade dos atos dos agentes administrativos e também como um conjunto de valores jurídicos e políticos constitucionalmente estabelecidos (MEIRELLES, 2014, p. 91-95; FUNGHI, 2011; ARRUDA NETO, 2010).

\footnotetext{
${ }^{10}$ Ver, por exemplo, BRASIL. Tribunal Regional da Quarta Região. Ação Cível no 2000.71.00.009347-0/RS. Relator: João Batista Pinto Silveira. DJU, 10 ago. 2005 (estendendo direitos previdenciários a casais homossexuais porque a Constituição Federal tem um compromisso com a cidadania do povo brasileiro, o que é atestado pela consagração do princípio da dignidade humana como princípio constitucional fundamental). BRASIL. Tribunal de Justiça do Rio Grande do Sul. Ação Cível $n^{\circ}$ 70016239949. Órgão Julgador: $7^{a}$ Câmara Cível. Relator: Luiz Felipe Brasil Santos. 20 dez. 2006 (negando provimento à apelação que procurava anular decisão que reconheceu uma união homossexual como união estável sob o argumento de que a Constituição Federal deve reconhecer novas perspectivas culturais e relações sociais, salvaguardando assim os direitos de todos os cidadãos em busca de tutela jurisdicional).
} 
A Administração Pública também é regida pela primazia do interesse público, o que pode ser genericamente pensado como a defesa da prioridade do bem-estar da comunidade em relação aos interesses privados. Embora o sistema jurídico deva proteger as liberdades individuais, elas não podem ter prevalência em todas as situações. Pelo contrário, a vida em sociedade requer a análise da possibilidade do estabelecimento de parâmetros para a consideração da preponderância da proteção de interesses dos diferentes setores da sociedade nas diversas situações. A democracia é um regime político que implica o exercício coletivo do poder por meio de normas jurídicas, sendo que elas determinam as formas como as instituições estatais devem atuar para atender os objetivos da comunidade. O Estado representa uma instância que, além de ter a atuação pautada por normas jurídicas, também precisa trabalhar para alcançar os propósitos estabelecidos pelos cidadãos por meio de seus representantes. Tais intenções são vistas como o conjunto de ações que procuram atender as necessidades humanas nas suas variadas expressões. Elas adquirem conteúdo específico por meio dos princípios e dos direitos fundamentais. Assim, a atuação da Administração Pública só pode ser legítima quando há plena consonância com os interesses dos cidadãos, expressos nas normas jurídicas. Os conceitos de justiça e solidariedade social determinam que a ação estatal deve alcançar a garantia das melhores condições de vida para os membros da comunidade política como um todo (CARVALHO, 2008, p. 61-63).

O conceito de interesse público implica a defesa do bem comum e também a existência de um referencial ético a partir do qual agentes estatais devem guiar suas ações. Tendo em vista os elementos normativos que estruturam nosso sistema constitucional, tais como a promoção da inclusão social, podemos adotar o entendimento de que políticas públicas destinadas a afirmar a cidadania de minorias estão em consonância com esse preceito. Não podemos perder de vista a diferenciação entre a dimensão subjetiva e a objetiva dos direitos fundamentais: enquanto a primeira afirma a universalidade dos direitos, a segunda descreve os valores adotados pela comunidade política que funcionam como princípios axiológicos do nosso sistema jurídico. A promoção dessa categoria de direitos expressa um comprometimento constitucional ao impor ao Estado os objetivos que são elementos centrais da ordem jurídica. A prática da diversidade possibilita a afirmação do aspecto objetivo dos direitos fundamentais, ao promover, como interesse público de primordial importância, a integração de minorias raciais. Garantir acesso a postos de trabalho a grupos sociais marginalizados possibilita então a melhoria de condições de vida de um grupo que compõe metade da população brasileira (SARMENTO, 2003, p. 252-270).

Porém, a defesa da inclusão racial como um interesse público deve ser analisada tendo em vista os possíveis benefícios que esse processo poderá trazer para a sociedade brasileira como um 
todo. Podemos identificar uma correlação clara entre o conceito de diversidade e o princípio da eficácia, uma exigência de que os órgãos públicos ofereçam seus serviços com a maior diligência possível. Mais do que um parâmetro que observa a legalidade dos atos públicos, a eficácia determina que as instituições estatais devem sempre ter como meta o atendimento, da forma mais proveitosa, das necessidades da comunidade. O dever de otimização dos recursos públicos é parte importante desse princípio, um requisito pautado na noção de que as instituições estatais devem objetivar a eficiência econômica. Mas os doutrinadores observam que o princípio da eficácia não implica apenas uma exigência de racionalidade financeira. Ele também envolve a eleição dos meios mais adequados para a efetivação dos interesses da comunidade. Assim, a eficácia administrativa deve ser interpretada também à luz dos direitos fundamentais e dos objetivos do nosso sistema jurídico, notoriamente a afirmação da justiça social (JUSTEN FILHO, 2012, p. 182). Se por um lado ele guarda relações próximas com o princípio da economicidade, exigindo então o uso racional dos recursos públicos, ele também se aproxima do princípio da moralidade, ao ter como propósito a realização dos interesses da coletividade da forma mais adequada. A otimização dos resultados e a maximização das finalidades funcionam então como critérios que podem racionalizar a atividade estatal, dando-lhe direções para a concretização da vontade pública. Em resumo, o princípio da eficácia congrega interesses de racionalização da atividade estatal e também o interesse em prestar o máximo de garantias aos administrados (CARVALHO, 2012, p. 185-188).

Creio que podemos identificar a partir dessas considerações situações nas quais a adoção de cotas raciais em concursos públicos poderia melhorar as condições de vida de vários grupos, por meio da realização conjunta dos princípios da moralidade pública, do interesse público e da eficácia.

Aqueles que classificam cotas raciais no serviço público como inconstitucionais argumentam que a meritocracia deve ser o parâmetro a ser seguido para a seleção de funcionários. Embora essa afirmação seja plausível, ela não condiz com a complexidade das funções estatais em uma realidade caracterizada pelo pluralismo racial. A meritocracia não pode ser pensada como condição única para a realização de interesses públicos, porque seu alcance depende de outros fatores que estão além da consideração desse preceito. Aquelas pessoas que vão servir aos interesses da comunidade precisam ter qualidades que, muitas vezes, estão além do conhecimento acadêmico. O nosso País é composto por uma diversidade imensa de comunidades que formulam demandas distintas, e as pessoas que são selecionadas para cargos públicos devem estar preparadas para servi-las. Assim, a possibilidade de oferecimento de serviço público mais eficaz não se resume ao conhecimento técnico: ela também pode decorrer da experiência pessoal dos candidatos para um 
determinado cargo, experiência que tem origem na vivência desses indivíduos como membros de grupos minoritários. Essa afirmação baseia-se nos estudos já mencionados, que demonstram os benefícios trazidos por um corpo diversificado de funcionários: quanto maior o pluralismo de pessoas, maior a capacidade de solução de problemas surgidos em sociedades complexas.

Pensemos então em alguns exemplos concretos. Muitas pessoas classificariam um concurso para a seleção de profissionais de saúde como um processo que deveria recrutar apenas aquelas pessoas que têm o maior conhecimento das ciências médicas. Isso demonstraria que elas são as mais qualificadas para exercer os serviços em questão. Não há dúvidas de que as instituições estatais devem procurar profissionais competentes, mas os que defendem essa posição ignoram as diferentes demandas que surgem em função do multirracialismo presente no Brasil. A meritocracia não possibilita a seleção das pessoas mais competentes para realizar funções estatais em todas as situações. Um aluno ou aluna de ascendência ameríndia estará mais capacitado para desempenhar essa função nas comunidades indígenas porque ele ou ela possivelmente fala a mesma língua dos seus futuros pacientes, porque ele ou ela também tem conhecimento do significado cultural da doença dentro da cultura de sua nação, além de poder se relacionar de forma mais empática com os membros daquela comunidade. O mesmo raciocínio é válido para aqueles profissionais que atuariam dentro de uma comunidade quilombola. Um médico branco criado dentro de um centro urbano também poderia exercer suas funções adequadamente, mas provavelmente não de forma tão satisfatória como um membro daquela comunidade que se beneficia de cotas em um concurso público. Assim, a existência de cotas nas universidades e nos concursos públicos permite a formação de um quadro de funcionários mais apto a compreender e responder à pluralidade de demandas feitas aos profissionais do sistema público de saúde. Cotas raciais para minorias raciais nas universidades e em concursos públicos de saúde também podem ser uma das soluções para os problemas de discriminação institucional sofridos por negros e pardos no sistema público de saúde, motivo de condenação do Brasil por órgãos internacionais de direitos humanos. Embora a qualidade desses serviços seja um problema que afeta todas as pessoas, a raça dos indivíduos surge como um obstáculo adicional ao acesso a tratamento médico, mesmo quando todas as outras variáveis são eliminadas. Em função disso, a maior presença de profissionais negros nesse setor deve ser vista como uma finalidade importante da Administração Pública, porque tem o potencial de melhorar a qualidade do serviço médico fornecido a esse segmento populacional (KALCKMAN et al., 2007).

Podemos indicar ainda outra situação na qual a diversificação racial do corpo de funcionários públicos pode melhorar a qualidade dos serviços prestados à população. Sabemos que afrodescendentes são vítimas constantes de discriminação racial na nossa sociedade, mas poucas 
pessoas foram condenadas por crimes de racismo até o presente momento da nossa história. A ideologia da democracia racial ainda influencia promotores e juízes, cargos ocupados majoritariamente por pessoas brancas de classe média alta - fundamentalmente, por homens brancos de classe média alta ${ }^{11}$. O racismo permanece um crime sem consequências sociais no nosso País porque muitos promotores e promotoras, juízes e juízas desconsideram o caráter discriminatório dessa prática, algo decorrente da ideia de que ele não expressa ódio ou desprezo racial. Como pessoas brancas de classe média alta não têm a experiência social do racismo, elas não sabem como esse problema afeta a vida de afrodescendentes. Além disso, a desconsideração do racismo cumpre um papel ideológico, porque permite a manutenção de uma imagem positiva do próprio grupo perante a sociedade (RACUSEN, 2004; VAN DIJK, 1994). Temos fortes razões para acreditar que a presença de um número maior de homens negros e de mulheres negras no Ministério Público e nos tribunais poderia contribuir para a diminuição do racismo no País, por meio de uma ação mais eficaz do Judiciário. A diversidade racial pode contribuir para a solução desse problema ao incorporar pessoas que têm a vivência social do racismo e que não estão comprometidas com interesses de grupo. Embora todos os indivíduos comprometidos com a democracia saibam que o racismo afronta a dignidade humana, eles não têm conhecimento de como ele opera no cotidiano da população negra e ameríndia. Dessa forma, a diversificação racial do sistema judiciário permite que essa instituição pública possa apresentar soluções mais adequadas à demanda social de tratamento igualitário entre grupos sociais, o que obviamente pode ser considerado como um interesse público de primeira ordem.

Afirmamos que a diversidade justifica a adoção de cotas raciais para o acesso a cargos públicos, mas também devemos defendê-la como um critério para a promoção às posições mais elevadas das instituições estatais. Isso se deve ao fato de que as instâncias mais altas de deliberação dentro desses órgãos também precisam espelhar o pluralismo racial existente na nossa sociedade. Quanto maior a participação de pessoas de diversos grupos raciais nos processos decisórios, maior será a legitimidade da ação estatal. Por exemplo, as estatísticas de prisões e mortes de negros por policiais brancos apontam de forma bastante clara a extrema importância da diversificação dos mais altos cargos de comando nas polícias militares no Brasil. A vasta maioria desses assassinatos decorre de ação policial arbitrária, sendo que os agentes raramente são investigados (SINHORETTO; SILVESTRE; SCHILTTER, 2014). Isso só pode ser explicado por uma cultura institucional baseada em estereótipos raciais negativos, cultura formada nas mais altas esferas de

\footnotetext{
11 Ver Censo do Poder Judiciário, disponível em: <http://www.cnj.jus.br/images/dpj/CensoJudiciario.final.pdf>.
} Acesso em: 8 dez. 2015. 
poder das corporações militares - grupo predominantemente branco. A maior presença de homens e mulheres negros nos órgãos responsáveis pela condução da ação policial pode ser um ponto de partida para a transformação de uma realidade que se torna mais brutal a cada dia.

A defesa de cotas raciais como uma política pública que pode fomentar a realização do princípio do interesse público e o da eficácia oferece subsídios para refutarmos alguns argumentos defendidos por aqueles que condenam essas iniciativas. Muitos alegam que elas são discriminatórias porque impedem a concorrência igualitária entre negros e brancos; o privilégio dado a pessoas negras excluem brancos de forma injusta. Devemos ter em mente o fato de que o conceito de discriminação implica a intenção de impor um tratamento desvantajoso a alguém; pretende-se assim excluir certos grupos de indivíduos com o objetivo de mantê-los em uma situação de subordinação. A própria definição desse conceito já demonstra a impossibilidade de afirmarmos que cotas raciais são práticas discriminatórias contra brancos: as instituições governamentais não pretendem estigmatizar ou subordinar esse segmento populacional. Pelo contrário, cotas raciais podem claramente realizar os interesses de diversos setores da sociedade, ao favorecer a prestação de serviços mais eficazes a vários grupos sociais. A inclusão desses grupos beneficia toda a sociedade porque concretiza um dos objetivos da sociedade brasileira: a eliminação da marginalização social, um dos componentes da moralidade que guia a ação dos órgãos públicos. Embora elas reduzam as possibilidades de candidatos brancos terem acesso a cargos públicos, ações afirmativas não podem ser consideradas como armas de subordinação racial. A vida em uma sociedade implica a adoção de critérios para o acesso a oportunidades que são escassas por natureza; ações afirmativas são apenas um desses critérios, sendo que eles podem ser legalmente e moralmente justificados (KENNEDY, 2013, p. 109-111; FRIEDMAN, 2011, p. 153-155).

Certos autores argumentam que cotas raciais contrariam o princípio da meritocracia, um preceito que deve orientar a distribuição de oportunidades nas sociedades liberais. Lani Guinier apresenta uma resposta particularmente engenhosa para essa objeção a ações afirmativas. Ela propõe a substituição da base individualista do conceito de meritocracia por uma orientação social. Sob essa perspectiva, a meritocracia transforma-se em um princípio democrático porque é preciso atribuir oportunidades àqueles que podem alcançar os objetivos sociais de forma mais eficaz. Essa concepção democrática da meritocracia, assevera a autora, deve guiar a atuação das instituições responsáveis pela preparação de profissionais; notoriamente, instituições de ensino superior. Da mesma forma, outras instituições públicas e privadas também devem atuar na mesma direção, porque a diversidade potencializa a inclusão de grupos minoritários direta e indiretamente, além de permitir melhor qualidade dos serviços públicos (GUINIER, 2015, p. 26-45). Essa linha de 
raciocínio vai ao encontro do que já afirmamos: a democratização do acesso a oportunidades profissionais permite que as instituições estatais estejam mais capacitadas para prover serviços de forma mais adequada para a sociedade. A observação de uma meritocracia estrita contribui para a manutenção daqueles que se encontram em uma situação de vantagem estrutural em função dos processos de exclusão social que têm como objetivo manter oportunidades nas mãos de grupos majoritários.

A alegação de que ações afirmativas promovem conflito racial é um das teses preferidas dos seus opositores. Eles também alegam que elas contribuirão para a disseminação de estereótipos negativos que afetarão os próprios beneficiários, além de diminuir a qualidade das universidades. Bem, a adoção de cotas raciais nas instituições brasileiras de ensino superior tem surtido efeitos extremamente positivos; podemos dizer que essa é uma política pública muito bem sucedida. Ao contrário do que seus opositores alegam, as cotas raciais trouxeram melhorias reais para os seus beneficiários e também para as instituições que as adotaram. Os relatórios divulgados por muitas universidades demonstram que o rendimento médio dos alunos cotistas está, em muitos casos, acima da média do aproveitamento escolar dos alunos que entram nas universidades pelo processo tradicional. Esses dados podem ser interpretados como forte evidência de que cotistas não se sentem inferiorizados por supostos estereótipos; eles provavelmente teriam um desempenho inferior aos dos outros alunos se esse fosse o caso. Além disso, os que se beneficiam de cotas raciais as classificam como uma forma de justiça social, e não como um privilégio racial. Afinal, eles vivem em uma sociedade na qual oportunidades profissionais e acadêmicas estão maciçamente concentradas nas mãos de pessoas brancas, o que os leva a ver o ideal de meritocracia com imenso ceticismo $^{12}$.

$\mathrm{O}$ argumento de que cotas raciais prejudicam negros porque lançam dúvidas sobre a competência profissional e acadêmica dos membros desse grupo está baseado no pressuposto de que esses estereótipos nunca existiram. Esta afirmação não poderia estar mais longe da verdade. Estereótipos negativos sobre a capacidade intelectual de pessoas de ascendência ameríndia e africana sempre foram utilizados para impedir o acesso igualitário desses indivíduos a oportunidades profissionais durante toda a história brasileira. Os que utilizam esse argumento desconhecem o fato de que desigualdades materiais e desigualdades de status são duas dimensões de todos os processos de estratificação social; negros e indígenas não estão em uma situação de

\footnotetext{
${ }^{12} \mathrm{O}$ desempenho acadêmico de alunos cotistas tem sido objeto de vários estudos nos últimos anos. Ver, por exemplo, VELLOSO, Jacques, Cotistas e não-cotistas: rendimento dos alunos da Universidade de Brasília. Cadernos de Pesquisa, v. 39, n. 137, p. 621-644, 2009; MATTOS, W. R. Cotas para afrodescendentes na Universidade do Estado da Bahia: uma exposição comentada. In: FERES JÚNIOR, J.; ZONINSEIN, J. (Org.). Ação afirmativa e universidade; experiências nacionais comparadas. Brasília: Editora da UnB, 2006, P. 166-182.
} 
pobreza apenas em função de disparidades de classe social. A situação de desvantagem material desses grupos decorre da constante circulação de representações negativas sobre eles no plano cultural, mecanismo que garante tratamento privilegiado a pessoas brancas, as quais compõem um grupo representado sempre positivamente. Esse é o mesmo processo que garante tratamento privilegiado de homens em relação a mulheres e também de heterossexuais em relação a homossexuais. Quaisquer iniciativas destinadas a promover justiça corretiva encontrará resistência por parte dos grupos que obtêm vantagens injustas em função da circulação de falsas generalizações que legitimam práticas discriminatórias.

\section{CONCLUSÃO}

O nosso percurso demonstrou uma clara compatibilidade entre a dimensão substantiva da diversidade e princípios que regem a nossa ordem jurídica. A sua prática tem importância instrumental para a construção de uma sociedade igualitária, por promover a participação de minorias raciais aos processos decisórios, um fator importante para a efetivação da democracia no Brasil. Esse ideal dificilmente poderá ser alcançado em uma nação na qual o mesmo grupo racial controla praticamente todas as instituições públicas e privadas. A diversidade fomenta a igualdade de participação dentro da esfera pública ao possibilitar que minorias raciais atuem de forma mais efetiva nas instituições que criam normas destinadas a regular toda a sociedade. Esse preceito enseja a criação de políticas sociais que atendam as demandas dos diversos setores da nação brasileira, pois medidas universais isoladas não são capazes de alcançar a inclusão. A luta pela justiça racial é muitas vezes frustrada porque muitos agentes estatais são socializados a partir de uma cultura pública que torna as desigualdades sociais invisíveis.

A análise da diversidade indica a grande relevância que a adoção de cotas raciais pode ter para a realização tanto do princípio do interesse público quanto da eficiência. Ações afirmativas possibilitam a consecução do primeiro porque a Administração Pública, ao incluir um número maior de afrodescendentes e ameríndios, impulsiona a inclusão de membros de grupos severamente discriminados no mercado de trabalho ao longo de toda a história do nosso País. Ações afirmativas podem ser justificadas a partir da ideia de justiça reparativa, principalmente quando consideramos o fato de que os órgãos governamentais estão legalmente obrigados a eliminar formas de marginalização. O Estado brasileiro contribuiu de várias formas para a opressão racial do povo negro e do povo indígena, motivo pelo qual ele está moral e juridicamente obrigado a criar iniciativas que possam reverter os problemas por ele causados. Mas essa política pública também 
possibilita a criação de uma sociedade mais racialmente integrada, ao funcionar como um mecanismo que permite maior participação de minorias raciais em cargos de prestígio e poder.

A influência do discurso da democracia racial no debate político sobre ações afirmativas frequentemente obscurece os objetivos que essa política pública procura alcançar. Os seus detratores argumentam que ela promove uma racialização da sociedade brasileira, o que compromete uma suposta ética pública de tratamento igualitário entre grupos raciais. Esse argumento esbarra no fato de que a miscigenação racial e cultural não é um processo antagônico ao racismo, pois ele tem servido historicamente para escamotear tanto a discriminação racial quanto o privilégio branco. Mas a miscigenação pode ser defendida como um objetivo a ser alcançado pela sociedade brasileira e as cotas raciais são instrumentos importantes para o alcance dessa finalidade. Sejam elas mecanismos reparatórios ou meios de promoção da integração racial, essas medidas permitem a realização de ideais democráticos. Ações afirmativas criam as condições para que grupos minoritários tenham acesso ao processo decisório, facilitando assim a participação deles nas decisões que afetam todos os segmentos sociais. A miscigenação do círculo do poder é, portanto, um passo necessário para o alcance da inclusão social de segmentos da população que ocupam uma posição subalterna desde a fundação do nosso País.

\section{REFERÊNCIAS}

ABRAHAM, Morris B. Affirmative action: fair shakers and social engineers. Harvard Law Review, v. 99, n. 5, p. 1312-1326, 1985.

ANDERSON, Terry H. The pursuit of fairness: a history of affirmative action. Oxford: Oxford University Press, 2005.

ARRUDA NETO, Pedro Thomé de. Reforma do Estado e evolução dos modelos de gestão pública no Brasil: a democracia deliberativa como fundamento de uma nova administração pública constitucional. Revista de Direito Administrativo, v. 253, p. 133-158, 2010.

ARTHUR, John. Race, racism, and the burdens of history. Cambridge: Cambridge University Press, 2007.

AZEVEDO, Célia Maria Marinho de. Cota racial e Estado. Abolição do racismo ou direito de raça? Cadernos de Pesquisa, v. 34, n. 121, p. 213-239, 2004.

AZEVEDO, Damião Alves. A justiça e as cores. A adequação constitucional das políticas públicas afirmativas voltadas para negros e indígenas no ensino superior a partir da teoria discursiva do direito. 2007. 361 f. Dissertação (Mestrado em Direito) - Faculdade de Direito, Universidade de Brasília, Brasília, 2007. 
BARROSO, Luis Roberto. Neoconstitucionalismo e constitucionalização do direito. In: QUAREMA, Regina et al. (Ed.). Neoconstitucionalismo. Rio de Janeiro: Forense, 2009.

BELL, Derrick. Diversity Distractions. Columbia Law Review, v. 103, n. 6, p. 1622-1633, 2003. . Brown v. Board of Education and the interest-convergence dilemma. Harvard Law Review, v. 93, n. 2, p. 518-533, 1979. . Race, racism and American law. Nova York: Aspen Publishers, p. 19-73, 2008. Racial realism. Connecticut Law Review, v. 24, n. 2, p. 363-379, 1991.

BELL, Myrth P. Diversity in organizations. Mason: South Western, 2007.

BLACKMON, Douglas. Slavery by another name: the re-enslavement of black Americans from the Civil War to World War II. Ithaca: Anchor, 2009.

BOYLAN, Michael. Affirmative action: strategies for the future. Journal of Social Psychology, v. 33, n. 1, 2002.

BROWN, Michael K. et al. Whitewashing race: the myth of a colorblind society. Berkeley: University of California Press, 2005.

CARVALHO, Raquel Melo Urbano de. Curso de direito administrativo. São Paulo: JusPodivm, 2008.

CHO, Sumi. Post-racialism. Iowa Law Review, v. 89, n. 6, p. 1591-1641, 2009.

COX, Taylor; BLAKE, Stacy. Managing cultural diversity: implications for organization competitiveness. The Executive, v. 5, n. 3, p. 45-55, 1991.

CROSBY, Faye. Understanding affirmative action. Basic and Applied Social Psychology, v. 15, n. $1,1991$.

CUMMINGS, Pund. Grutter v. Bollinger, Clarence Thomas, affirmative action, and the treachery of originalism. Harvard Blackletter Law Journal, v. 21, n. 1, p. 1-73, 2005.

DUARTE, Luis Fernando Dias. Pungente retrato do universalismo apunhalado. Horizontes Antropológicos, v. 11, n. 23, p. 255-257, 2005.

DWORKIN, Ronald. Taking rights seriously. Cambridge: Harvard University Press, 1977.

ESTLUND, Cynthia. Putting Grutter to work: Diversity, integration and affirmative action in the workplace. Berkeley Journal of Employgment and Labour Law, v. 26, n. 1, 2005.

FARIA E SILVA, Paulo Penteado. Cotas raciais nas universidades públicas. São Paulo: Arraes Editores, 2012. 
FARREL, Robert C. Affirmative action and the "individual” right to equal protection. University of Pittsburg Law Review, v. 71, n. 1, p. 241-277, 2009.

FISS, Owen. Groups and the equal protection clause. Philosophy and Public Affairs, v. 5, n. 2, p. 107-177, 1976.

FREDMAN, Sandra. Redistribution and recognition: reconciling inequalities. South African Journal of Human Rights, v. 23, n. 3, p. 214-234, 2007,

FRY, Peter et al. Divisões perigosas: políticas raciais no Brasil contemporâneo. Rio de Janeiro: Record, 2007.

FRY, Peter. Politics, nationality and the meanings of “race” in Brazil. Daedalus, v. 129, n. 2, 2000.

FUNGHI, Luís Henrique Baeta. Da dogmática autoritária à administração democrática. Revista de Direito Administrativo, v. 257, p. 213-239, 2011.

GOMES, Joaquim Barbosa. Ação afirmativa e princípio constitucional da igualdade. Rio de Janeiro: Renovar, 2001.

GROSS, Karine Pereira. Retóricas em disputa: o debate entre intelectuais em relação às políticas de ação afirmativa para estudantes negros no Brasil. 2008. 185 f. Tese (Doutorado em Sociologia Política) - Universidade Federal de Santa Catarina, Florianópolis, 2008.

GUIMARÃES, Antônio Sérgio Alfredo. Racismo e antirracismo no Brasil. São Paulo: Editora 34, 2012.

GUINIER, Lani. Confirmative action. Law and Social Inquiry, v. 25, n. 3, p. 565-583, 2000.

The Tyranny of meritocracy. Boston: Beacon Press, 2015.

HANCHARD, Michel. Orpheus and power. Princeton: Princeton University Press, 1994.

HASENBALG, Carlos. Discriminação e desigualdades raciais no Brasil. Belo Horizonte: Editora da UFMG, 2005.

HAWKINGS, Stacy. A deliberative defense of diversity. Columbia Journal of Race and Law, v. 2, n. 1, 2012.

HUNT II, Cecil J. The color of perspective: white innocence and the constitutional rhetoric of white innocence. Michigan Journal of Race and Law, v. 11, n. 3, p. 477-554, 2005.

IKAWA, Daniela. Ações afirmativas em universidades. Rio de Janeiro: Lumen Juris, 2008.

JUSTEN FILHO, Marçal. Curso de direito administrativo. Curitiba: RT, 2013.

KALCKMAN, Susana. Racismo institucional: um desafio para a equidade no SUS. Saúde $e$ Sociedade, v. 16, n. 2, p. 146-155, 2007. 
KARST, Kenneth. Equal citizenship under the Fourteenth Amendment. Harvard Law Review, v. 91, n. 1, p. 1-68, 1976.

KAUFMANN, Roberta Fragoso. Ações afirmativas à brasileira: necessidade ou mito. Curitiba: Livraria do Advogado, 2005.

KENNEDY, Randall. For discrimination. Race, affirmative action and the law. New York: Pantheon Books, 2013.

Persuasion and distrust: a comment on the affirmative action debate. Harvard Law Review, v. 99, n. 4, p. 1327-1346, 1985.

KLARE, Karl. Legal Culture and transformative constitutionalism. South African Journal of Human Rights, v. 14, n. 1, p. 146-188, 1998.

LAWRENCE III, Charles. Each other's harvest: diversity's deeper meaning. University of San Francisco Law Review, v. 31, n. 2, p. 747-778, 1996.

LOPEZ, Ian Haney. “A nation of minorities”: race, ethnicity and reactionary colorblindness. Stanford Law Review, v. 59, n. 3, 2006, p. 1001-1028.

MAGGIE, Yvonne; FRY, Peter. A reserva de vagas para negros nas universidades públicas. Estudos Avançados, v. 18, n.50, p. 67-80, 2004.

MARQUES NETO, Floriano Peixoto de Azevedo. Regulação estatal e interesses públicos. São Paulo: Malheiros Editores, 2011.

MASSEY, Douglas; DENTON, Nancy. American apartheid: segregation and the making of the underclass. Cambridge: Harvard University Press, 1999.

MELLO, Celso Antônio Bandeira de. Curso de direito administrativo. São Paulo: Malheiros Editores, 2014.

MINHOTO, Antônio Celso Baeta. Da escravidão às cotas. A ação afirmativa e as cotas raciais. Rio de Janeiro: Boreal, 2013.

MOREIRA, Adilson José. O mito da inocência branca no debate brasileiro sobre ações afirmativas. In: JUBILUT, Liliana Lyra; BAHIA, Alexandre Gustavo Melo Franco; MAGALHÃES, José Luiz Quadros de (Org.). Direito à diferença. Aspectos de proteção específica às minorias e aos grupos vulneráveis. São Paulo: Saraiva, 2013, p. 61-94.

NASCIMENTO, Abdias do; NASCIMENTO, Elisa Larkin. Dance of deception: A Reading of race relations in Brazil. In: HAMILTON, Charles et al. Beyond racism: racism and inequality in Brazil, South Africa and the United States. Boulder: Lynne Rienner Publishers, 2002, p. 105-156.

PIETRO, Maria Sylvia Zanella di. Direito administrativo. São Paulo: Atlas, 2014.

POWELL, Cedric Merlin. Blinded by color: the new equal protection, second reconstruction, and affirmative action. University of Miami Law Review, v. 51, n. 2, p. 192-270, 1997.

Revista da Faculdade de Direito - UFPR, Curitiba, vol. 61, n. 2, maio/ago. 2016, p. 117 - 148 
POWELL, John A. Post-racialism or targeted individualism? Denver University Law Review, v. 86, n. 3, p. 785-806, 2009.

RACUSEN, Seth. The ideology of Brazilian nation and the Brazilian legal theory of discrimination. Social Identities, v. 10, n. 6, p. 775-809, 2004.

ROCHA, Carmen Lúcia Antunes. Ação afirmativa - o conteúdo democrático do princípio da igualdade jurídica. Revista Trimestral de Direito Público, v. 15, p. 85-99, 1996.

Ação afirmativa: o conteúdo democrático do princípio da igualdade. Revista de Informação Legislativa, v. 33, n. 131, p. 283-295, 1996.

ROOSEVELT JR, Thomas R. Building on the promise of diversity. Nova York: Amacom, 2006.

ROSENFELD, Michel. Affirmative action, justice, and equality: a philosophical and constitutional appraisal. Ohio State Law Journal, v. 46, n. 3, 1985.

SARMENTO, Daniel. A dimensão objetiva dos direitos fundamentais: fragmentos de uma teoria. In: SAMPAIO, José Adércio Leite (Ed.). Jurisdição constitucional e os direitos fundamentais. Belo Horizonte: Del Rey, 2003, p. 252-313.

SCALIA, Antonin. The disease as cure: "in order to get beyond racism, we must first take account of race”. Washington University Law Quarterly, v. 1979, n. 1, p. 147-157, 1979.

SILVA NETO, Paulo Penteado de Faria. Cotas raciais nas universidades púbicas. Estratégias argumentativas, lógica informal e teoria da argumentação. Belo Horizonte: Arraes, 2012. 221pp.

SILVA, José Afonso da. Curso de direito constitucional positivo. São Paulo: Malheiros, 2011.

SKRENTNY, John D. The minority rights revolution. Cambridge: Harvard University Press, 2002.

SOUZA, Jessé. A ralé Brasileira. Como é e como vive. Belo Horizonte: Editora da UFMG, 2009.

STEINBERG, Steven. The ethnic myth: race, ethnicity, and class in America. Boston: Beacon Press, 1989.

TELLES, Edward. Race in another America: the importance of skin color in Brazil. Princeton: Princeton University Press, 2005.

VAN DIJK, Teun. Elite discourse and racism. Londres: Sage, 1994.

WEST, Robin. Conservative and progressive constitutionalism. Michigan Law Review, v. 88, n. 3, p. 641-721, 1991. 


\title{
MISCEGENATING THE CIRCLE OF POWER: AFFIRMATIVE ACTION, RACIAL DIVERSITY, AND DEMOCRATIC SOCIETY
}

\begin{abstract}
This article defends the constitutionality of racial quotas in selection processes for public employment by reverting the premises of an argument commonly deployed against this policy. Many of its opponents claim that affirmative action is an inherently problematic measure because of the difficulty in identifying its beneficiaries in a racially mixed society such as ours. They also argue that racial and cultural amalgamation allowed the construction of a public morality that favors harmonious race relations among blacks and whites. This paper recognizes the relevance of racial mixing in the formation of the Brazilian national identity, but it supports racially conscious initiatives because those who control the majority of private and public institutions belong to the same racial group. This racial stratification is the product of various processes of social exclusion that affect negatively those of African and Amerindian descent, the same mechanisms that concentrate social opportunities among the members of the dominant racial group. This paper utilizes a substantive notion of diversity and certain principles of public administration in order to advocate racial miscegenation of the circles of power, a necessary step toward the democratization of the Brazilian society.
\end{abstract}

\section{KEYWORDS}

Affirmative action. Miscegenation. Diversity. Equality. 